\title{
The Ethics of Care and its Alterations
}

\author{
Natália Fontes de Oliveira \\ Mestre em Literaturas em Expressão Inglesa / UFMG
}

\begin{abstract}
In this article I argue that in Toni Morrison's Sula and A mercy, the ethics of care is altered as characters resort to unconventional actions to survive and care for loved ones in a racist and sexist society. I suggest that these changes have many different implications for the characters.
\end{abstract}

KEYWORDS

Ethics of care, Sula, A mercy

To define an ethics of care is to welcome different discussions encompassing elements from various areas. It is pointless to try to devise a homogenous or single meaning of such a term. In this article, I first provide a discussion about the meaning of the expression "ethics of care”. I argue that to define an ethics of care is to welcome different discussions encompassing elements from various areas. It is pointless to try to devise a homogenous or single meaning of such a term, therefore, a working definition is adopted. Then, I focus on how the principles of an ethics of care are altered by the slave holding society in A mercy and by a society still marked by the consequences of slavery in Sula. The distortion causes many women bonds to rupture as family and social relations are inverted to best suit economic and ideological interests.

Critics have different opinions about how to delineate the boundaries for such a flexible term. It is argued that the main characteristic of the ethics of care is solidarity among the characters, as illustrated in Toni Morrison's Sula and A mercy. Even so, there is no assumption about the universality of the meaning of ethics of care as other definitions may still be accurate but are beyond the scope of this work. 
The ethics of care is characterized by vocabulary from distinct fields that try to delineate a clear notion of the term. It is important to consider that these ponderings and meanings are interwoven with complex notions and analogies, creating an intriguing discussion. A dialogue between feminist criticism and the studies on the ethics of care can be established as the discussion enhances the understanding of the definition of this vocabulary. The emergence of the feminist movement in the 1960s can be regarded as a rebellion against women's subordination to men, as well as against the supposed feminine nature of caring. ${ }^{1}$ Seen as limiting, caring was viewed as an obstacle incompatible with the incessant quest for women's independence. As the feminist movement becomes consolidated in several areas, various reflections on new and old themes have caught critics' attention. In this context, the ethics of care, once completely rejected, has recently appeared in the feminist agenda through alternative perspectives.

In a book dedicated to the subject, Virginia Held presents an approach with specific characteristics of the ethics of care, associating it with moral ethics and the ethics of justice. She initially defines ethics of care as a cluster of practices among individuals with horizon beyond family and friends, in fields such as medicine, law and international relations. ${ }^{2}$ Thus, the ethics of care is not limited to biological or social categorization as it occurs in different scenarios and refers to the cultivation of embracing acts that foster social connections and cooperation. In this sense, the ethics of care focuses on trust and in the response to the needs of others. On the other hand, the ethics of justice focuses on individual rights, equality and abstract notions. ${ }^{3}$ This distinction shows that the ethics of justice is different because it is concerned with individual rights, with the separation between one and the other.

In my analysis of Morrison's novels, I take into consideration Held's arguments to establish the ethics of care as being characterized by solidarity, mutual actions of concern and caring acts towards others. As Held adopts a maternal figure as the model of her analysis, she has received criticism from those who argue that she is perpetuating an ideal model of woman who cares for everyone. Even though she adopts a woman figure to illustrate her ponderings, her work is not necessarily based on essentialisms because the model is based on caring individuals, be they represented by a woman or a man. Nevertheless, she associates the mother figure with care and compassion as opposed to justice. As Selma Sevenhuijens argues,

\footnotetext{
${ }^{1}$ SEVENHUIJSEN. Citizenship and ethics of care: feminist considerations on justice, morality and politics, p. 5.

${ }^{2}$ HELD. The ethics of care: personal, political and global, p. 3.

${ }^{3}$ HELD. The ethics of care: personal, political and global, p. 15.
} 
this principle may erroneously reproduce arguments based on dichotomous oppositions. ${ }^{4}$ Held's distinction is, therefore, set on slippery paradigms because it opens space for a binary distinction between women and men by associating women with care and men with justice. Even though emphasis is given to Held's relevant definitions of the ethics of care, in my work I place no emphasis on women as essentially caring subjects or on a simplistic belief that caring is exclusively a feminine characteristic.

Sevenhuijsen does not assign motherhood a special space in the ethics of care because she believes such reference may result in the dependence on the mythological maternal figure. ${ }^{5}$ As is the case with the novels analyzed here, motherhood may be interwoven with the ethics of care, but such term is not limited to motherly expressions. This article shows how an ethics of care is present in motherhood and sisterhood bonding, showing how neither bond is seen as more powerful or superior, as alternative perspectives are used to challenge preconceived stereotypes commonly associated with such relationships. Although the scope of this paper is limited to women bonds, there is nothing that restricts the ethics of care only to women. Thus, other relevant aspects and manifestations of an ethics of care are mentioned whenever needed to enhance the discussion.

Cynthia Willet discussing maternal ethics, specifically in the context of slavery, points out the importance of challenging the "altruism-egoism dichotomy of traditional ethics". ${ }^{6}$ It is crucial to elaborate alternative characteristics of the ethics of care, which, although marked by solidarity among individuals, does not imply that there is an ideal selfless person involved. Also, bell hooks explains, "rather than seeing giving care as diminishing us, we will experience the kind of care giving that enriches the giver. It is fundamentally rooted in the ability to empathize". Hooks's comments are relevant because they stress the fact that, although caring has been perceived as a feminine trait and, therefore, has often been rejected as outdated, the focus now is on the positive aspect of care for both women and men. This topic does not place women in a passive and confining role, but rather highlights the benefits of caring or the problems arising from its rupture. As Gillespie and Kubitscheck emphasize, it

\footnotetext{
${ }^{4}$ SEVENHUIJSEN. Citizenship and ethics of care: feminist considerations on justice, morality and politics, p. 13.

${ }^{5}$ SEVENHUIJSEN. Citizenship and ethics of care: feminist considerations on justice, morality and politics, p. 17.

${ }^{6}$ WILLET. Maternal ethics and other slave moralities, p. 9.

${ }^{7}$ HOOKS. Sisters of the yam: black women and self-recovery, p. 168.
} 
is important to "reclaim caretaking by focusing on its empowering, generative aspects". Thus, the ethics of care can have healing aspects as individuals may benefit from such interactions.

This article focuses on how slavery and its aftermath alter the ethics of care among the characters in Sula and A mercy. The notion of an ethics of care is incompatible with slavery because this institution confines individuals to inhumane roles and disseminates a notion of superiority based on race which causes individuals to lack solidarity with each other as they incorporated a distorted view of care. I initially discuss how the alteration of the ethics of care affects motherhood in both novels. In Sula, the characters analyzed are Eva with her children Hannah and Plum, as well as Hannah and her daughter Sula. In A mercy, the characters chosen for analysis are Florens and her mother, because they have the central motherdaughter conflict. Then, I analyze how sisterhood is disturbed by the changes in the ethics of care illustrated in the novels. In Sula, Nel and Sula's close sisterhood bonding is severed because of a variation in the ethics of care that they cannot overcome. In A mercy, Lina's actions towards Sorrow are analyzed in light of the alteration of the ethics of care as they are both women slaves. It is important to note that in these novels, women characters resort to actions that are a reflection of a society tainted by slavery and its aftermath, as is the case with Rebekka, who eventually adopts a fallacious notion of the ethics of care. I focus on how the changes in the ethics of care force women to behave unexpectedly, and assert that their actions cannot be used to completely condemn them, nor simply classify them as good or bad.

In Sula, the alteration of the ethics of care greatly affects motherhood. Even though the women characters are forced to stray from the traditional representations of an ethics of care, they are nevertheless judged by such traditional paradigms. When Hannah asks Eva, if she ever played with them, Eva answers: “Play? Wasn’t nobody playin’ in 1895. Just 'cause you got it good now you think it was always this good?."9 Although Eva's answer might seem harsh, her experiences and constant struggles have shaped her way of showing her feelings and her practical attitude towards life. Another misunderstanding between Hannah and Eva happens when Hannah asks: "Mamma, did you ever love us?."10 She thinks for a second and answers: "No. I don’t reckon I did. Not the way you thinkin.”11 Once again, Eva’s responses

\footnotetext{
${ }^{8}$ GILLESPIE; KUBITSCHECK. Who cares? Women-centered psychology in Sula, p. 29.

${ }^{9}$ MORRISON. Sula, p. 68.

${ }^{10}$ MORRISON. Sula, p. 67.

${ }^{11}$ MORRISON. Sula, p. 67.
} 
are not the conventional outburst of explicit love that her daughter wants, but it does not mean that she does not love her children. In Eva's generation, mothers were lucky if they could manage to keep their children alive and close to them. As she is left by BoyBoy with young children to raise she has no time to think and express her emotions because she has to concentrate on finding a job to make ends meet, to feed her children and care for them, as they are too young to be left alone. For Eva, simply ensuring her children's survival is a demonstration of an overwhelming love. Hannah continues to question her "But Mamma, they had to be some time when you wasn't thinkin’ ‘bout...'.”12 and Eva replies:

No time. They wasn't no time. Not none. Soon as I got one day done here came a night. With you all coughin' and watchin' so TB wouldn't take you off and if you was sleeping' quiet I thought, O Lord, they dead and put my hand over your mouth to feel if the breath was comin' what you talkin' 'bout did I love you girl I stayed alive for you can't you get that through your thick head or what is that between your ears, heifer? ${ }^{13}$

Hannah does not understand the context from which her mother is speaking, the arduous days and nights Eva had to endure just to make sure her children remained alive and healthy. For Eva, this is the ultimate expression of love. This experience of feeling rejected by her mother greatly affects Hannah and has an impact on her feelings toward her own daughter Sula. Hannah interprets her mother's response according to the conventional motherly attributes which would classify Eva as loveless because she does not say she loves her children. But as Rich states: "Eva Peace (...) is forced to pour all her forces into fighting for her children's survival; her maternal love expresses itself in action to the last."14 Eva's love is explicit through her actions, but Hannah does not understand this important detail. Eva loves her so much that when she sees that Hannah is burning, she reacts quickly:

Eva knew there was time for nothing in this world other than the time it took to get there and cover her daughter's body with her own. She lifted her heavy frame up on her good leg, and with fists and arms smashed the windowpane. Using her stump as a support on the window sill, her good leg as a lever, she threw herself out of the widow. Cut and bleeding she clawed the air trying to aim her body toward the flaming, dancing figure. ${ }^{15}$

Eva is on her bedroom, on the top floor of the house, but she does not hesitate and jumps to try to reach Hannah on time to help her. Eva's desperate attempt to save Hannah illustrates the

\footnotetext{
${ }^{12}$ MORRISON. Sula, p. 69.

${ }^{13}$ MORRISON. Sula, p. 69.

${ }^{14}$ RICH. Of woman born: motherhood as experience and institution, p. xxvi.

${ }^{15}$ MORRISON. Sula, p. 76.
} 
immensity of her love. She has always loved Hannah but because of the alteration of the ethics of care, caused by her social, cultural and financial constraints, she does not express her emotions in the traditional way her daughter would like her to. Even so, when her children are hurting, as is the case with Hannah, Eva is unconcerned with the difficulty of saving them and is always ready to take action.

Likewise, Sula judges her mother with the same idealization of the maternal role and, like Hannah, she interprets the situation wrongly by placing unrealistic expectations on her mother. Sula suffers greatly when she hears her mother saying to her friends: "You love her, like I love Sula. I just don't like her. That's the difference.”16 Hannah and two other friends were talking about married life and children while Sula runs inside the house and overhears her mother's words. Sula does not understand the context her mother grew up in, the events she had been exposed to, and her way of reasoning about the world. In the same way Hannah fails to understand Eva, Sula is unable to contextualize Hannah's comments and understand her perspective. Hannah's reactions are probably the result of what she herself had gone through with her own mother, as she too feels rejected. Sula becomes lost and does not know exactly how to react to her mother or to the other people around her. When Eva is desperately trying to save Hannah from burning, she remembers that "she had seen Sula standing on the back porch just looking”. ${ }^{17}$ She is shocked by Sula's reactions and tries to convince herself that her granddaughter was probably numb from seeing her mother on fire. In fact, Sula's action is not easy to comprehend, but it is a direct consequence of the alteration of the ethics of care that negatively affects the characters. Sula cannot seem to distinguish between what is important or not, and what is instinctive or not. She is disappointed by Hannah not liking her, and she is unable to take any action as she is lost by what she experiences. Sula is paralyzed and does not seem to know what to do. The alteration of the ethics of care strangely affects Sula and her actions because she cannot cope with the feeling of maternal rejection derived from her misinterpretation of her mother's words.

As an adult, Sula places Eva in a retirement home. The event is briefly described by the impersonal narrator: "In April two men came with a stretcher and she didn't even have time to comb her hair before they strapped her to a piece of canvas.”18 Sula does not explain or warn her grandmother, but while talking to her best-friend Nel, she says: "She didn't

\footnotetext{
${ }^{16}$ MORRISON. Sula, p. 57.

${ }^{17}$ MORRISON. Sula, p. 78.

${ }^{18}$ MORRISON. Sula, p. 94.
} 
belong in that house. Digging around in the cupboards, picking up pots and ice picks.”19 Through her remark, it seems that just like Eva, she is being practical and taking action when something bothers her, except for the fact that Eva always acts on behalf of her family, and Sula pushes her loved ones away. Sula goes on to say: “I'm scared of her, Nellie. That's why... You don't know her. Did you know she burnt Plum? (...) It's true (...) And when I got back here she was planning to do it to me too". ${ }^{20}$ Sula does not understand her grandmother's actions towards Plum when he is not behaving right and she is afraid that because she and Eva are not getting along, Eva will react in the same manner. In turn, Eva becomes scared of Sula and, after their conversation, she only sleeps with her bedroom locked. The alteration of the ethics of care causes mistrust and miscommunication between the characters and weakens the women bonds as they react according to an often erroneous interpretation of events.

As briefly mentioned in the previous paragraph, the changes in the ethics of care also affect the mother-son relationship between Eva and Plum. After he returns from the war, he seems to suffer from shell-shock as he cannot insert back into the community. He quits his job and begins locking himself for days in his room to use drugs. Eva cannot stand watching him being slowly consumed by his drug addiction any longer. One night, she goes into his room "with a swing and a swoop she arrived at Plum's door and pushed it open with the tip of one crutch (...) she sat down and gathered Plum into her arms”. ${ }^{21}$ Eva holds him close and has mixed feelings because although she loves him, she cannot bear the fact that the son she loves is lost in a world of drugs. Eva recalls memories of his childhood and "lifted her tongue to the edge of her lip to stop the tears from running into her mouth. Rocking, rocking”, ${ }^{22}$ As she is holding and rocking him as if he were still a baby, showing her love for and concern about him, she becomes aware that he is not a child anymore, but as he refuses to live as an adult, she feel she has to interfere in his life. Eva decides to take action into her own hands and free him from his dependence on drugs. She goes into the kitchen to get gasoline and sets him on fire. Interestingly, he is not scared or desperate and the event is portrayed without conveying a violent image: "He opened his eyes and saw what he imaged was the great wing of an eagle pouring a wet lightness over him. Some kind of baptism, some kind of blessing, he thought

\footnotetext{
${ }^{19}$ MORRISON. Sula, p. 100.

${ }^{20}$ MORRISON. Sula, p. 100.

${ }^{21}$ MORRISON. Sula, p. 46.

${ }^{22}$ MORRISON. Sula, p. 47
} 
(...) he closed his eyes and sank back into the bright hole of sleep."23 Plum feels a certain tranquility as he believes he is experiencing a cleansing or a transcendental moment and he relaxes and falls into sleep. Eva may have seen her actions as extremely painful and difficult, but as a mother, she believes she has the obligation to save her son, and in this case, ending Plum's life is a way to put him out of his misery of drug addiction.

A reference to Morrison's Beloved is relevant here, because Sethe, a runaway slave, also struggles against the contradictions imposed on the black mother. As Sethe is fleeing from the plantation with her children, she becomes desperate when the slave hunter approaches. She is determined to save her children from slavery because she cannot imagine them suffering the same cruelties she has. She believes the only way to protect her baby daughter from the atrocities of slavery and set her free is by killing her. Carole Boyce Davies argues that "Sethe's violent action becomes an attempt to hold on to the maternal right and function." 24 The same reasoning can be applied to Eva because she believes that as a mother, it is her duty to save her son from his imprisoned in the world of drugs. Both Sethe and Eva cannot be judged as cruel mothers because their actions are a reflection of their past experiences and the alteration of the ethics of care. Like many mothers in slavery, who preferred to kill their children rather than to see them in such misery, Sethe in Beloved prefers to kill her baby daughter rather than to see her suffer a lifetime of slavery. Likewise, in Sula, Eva prefers to kill Plum and thus provide him with a possible way out of his enslavement to drugs.

Thus, it is important to reject dichotomous paradigms to classify characters, such as Eva and Sethe, as good or bad mothers because doing so contributes to the dissemination of the ideal and unattainable model of a perfect woman. hooks argues that "discussions of black subjectivity are often limited to the topic of representation of good and bad images". ${ }^{25}$ It is crucial to represent the characters and their actions moving beyond this binary distinction, especially in the context of slavery and its aftermath in which the ethics of care is altered, as the women characters might adopt unconventional actions to care for others.

In this sense, although Eva and Sethe's actions seem outrageous, they cannot be judged by ordinary notions of mothering. Eva is willing to sacrifice her life when she needs to support her children and when she tries to save Hannah from burning. She does whatever it

\footnotetext{
${ }^{23}$ MORRISON. Sula, p. 47.

${ }^{24}$ DAVIES. Black women, writing and identity: migrations of the subject, p. 139.

${ }^{25}$ HOOKS. Yearning: race, gender, and cultural politics, p. 19.
} 
takes to ensure her children's well being. But she cannot bear to see her children in great suffering and, in Plum's case, she refuses to continue to watch him suffer because of his addiction. Freedom is so precious for her that she cannot sit and watch passively as he destroys his life by being imprisoned to drugs. Although from moral standards she may not have the right to take away his life, her perspective and reasoning are different because she has experienced various hardships caused by the aftermath of slavery that alter the ethics of care.

Likewise, in A mercy, motherhood is affected by the changes in the ethics of care. Florens and her mother are slaves belonging to D’Ortega, a cruel Portuguese slave owner. Meanwhile Jacob, a tradesman in in D’Ortega's plantation to collect a debt, is convinced to take a slave as payment. Florens's mother, being a house slave, observes the situation and quickly offers Florens, her only daughter, to be taken by Jacob. There is a miscommunication between Florens and her mother, as she believes her mother did not love her, and thus, offered her to be taken away. In fact, as Florens's mother is sexually abused by D’Ortega, she is desperate for Jacob to take Florens away from the plantation. Florens does not understand her mother's action, which may be because she is young and does not fully comprehend how the context of slavery affects motherhood and bonds in general. In the last chapter of the narrative, Florens's mother shares her experiences and explains her reasons for asking Jacob to take her daughter. She sees in Jacob the only opportunity for Florens not to be sexually abused as she is and to have a better life, as she feels he is a less cruel owner than D'Ortega. It becomes clear that she acts to defend Florens in any way she can. Like many other black mothers whose "source of strength was not some mystical power attached to motherhood, but rather their concrete experiences as slaves”, ${ }^{26}$ Florens's mother finds the courage to send Florens away for her daughter's own good. The ethics of care shifts because the manifestation of solidarity and care is bound to slavery, and as an example, to care may mean for mothers to let of their children. Black mothers have to be considered according to the context of slavery which means that "envisioning mother-child separation [may be seen] as a form of caring". ${ }^{27}$ As it becomes clear, in the last chapter of the narrative, Florens's mother acts out of love, hoping to give her daughter a better life.

In addition, sisterhood also changes because of the alteration of the ethics of care. In Sula, Nel and Sula are best girlfriends, and their bond has many positive consequences in

\footnotetext{
${ }^{26}$ DAVIS. Women, race, and class, p. 29.

${ }^{27}$ HENDERSON. Pathways to fracture: African American mothers and the complexities of maternal absence, p. 44.
} 
their lives. However, their sisterhood is broken because of the changes in the ethics of care that determine Sula's unconventional actions and Nel's conservative views. When both are older, Nel marries Jude, and Sula leaves for college and, upon Sula's returns to the Bottom, their friendship is quickly reestablished. Nel is once again happy and confident as Sula brings more liveliness to her life, and Sula becomes more centered as Nel helps her reflect on her actions and about other people's feelings. Their sisterhood ruptures when one day Nel sees Sula and Jude having sex on her own bed. The event is described through Nel's perspective "they had been down on all fours naked, not touching except their lips right down there on the floor where the tie is pointing to, on all fours like (un huh, go on say it) like dogs". ${ }^{28}$ She is shocked and cannot believe what she is seeing and has difficulty describing the situation. She expects Sula to promptly give her an explanation: "I waited for Sula to look up at me any minute and say one of those lovely college words like aesthetic or rapport, which I never understood but which I loved because they sounded so comfortable and firm." ${ }^{29}$ Nel wants Sula to apologize and elaborate a fancy excuse for the event, but she does neither.

Nel judges Sula according to traditional views that stipulate Sula's action as morally erroneous and not a proper conduct for a best friend. But in Sula's mind, she did nothing improper because she has always dismissed society's conventions and, in turn, she is shocked that Nel reacts just like the traditional wives they once criticized. She is surprised by her best friend's behavior and comments: "Now Nel was one of them. One of the spiders whose only thought was the next rung of the web (...) she had given herself over to them.”30 Sula believes that Nel has assumed the conservative feminine role she loathes and is now against her free life style. She is unable to perceive the pain she causes Nel.

Although Sula's actions are controversial, she behaves as she usually does: acting on her desires and not forcing herself to follow any social conventions. Nel does not consider Sula's experience and beliefs because she focuses on the orthodox wrongness of such act. As Jane Bakerman mentions in her analysis of Sula, "the pattern of failure is set (...) they will be unable to cope with the pressures of society except by damaging themselves”. ${ }^{31}$ The alteration of the ethics of care creates the erroneous idea that Sula lacks solidarity towards Nel, and makes Nel seem too strict. In reality both care for each other, but they are unable to

\footnotetext{
${ }^{28}$ MORRISON. Sula, p. 105.

${ }^{29}$ MORRISON. Sula, p. 105.

${ }^{30}$ MORRISON. Sula, p. 120.

${ }^{31}$ BAKERMAN. Failures of love: female initiation in the novels of Toni Morrison, p. 551.
} 
communicate or to reach an understanding. Cedric Bryant argues that "Sula's and Nel's close bond of sisterhood is severely strained by the differences in their personalities". ${ }^{2}$ On the contrary, I propose that the differences between the girls empower them through their sisterhood and, the end of their friendship is caused by the changes in the ethics of care as Sula acts unorthodoxly. Both women become disconnected from each other and do not reestablish their friendship because they wrongly believe one does not care about the other anymore. Although their sisterhood is very strong, they eventually separate because of the alteration of the ethics of care. Although they still love each other, their actions become incomprehensible to one another.

In A mercy, sisterhood is also affected by the changes in the ethics of care. There is a clear corruption of the ethics of care when Lina is helping Sorrow give birth by the riverbank. As soon as Lina helps Sorrow deliver her first baby, she takes the baby: "Lina wrapped it in a piece of sacking and set it a-sail in the widest part of the stream and far below the beaver's dam". ${ }^{33}$ Lina tells Sorrow the baby is dead and quickly sets the child off into the river, giving no time for her to react. Sorrow believes she hears the baby cry and she suffers from the thought that her baby is drowning. She thinks about "her baby breathing water under Lina's palm to recede». ${ }^{34}$ From that point on, Sorrow completely mistrusts Lina and relies even more on Twin, her imaginary friend. Lina believes that the baby is Jacob's and realizes it would bring even more problems for them. In this case, Lina acts according to what she perceives to be a less damaging alternative for their lives. She is forced to make an unconventional compromise to ensure that she and Sorrow outlive the atrocities of slavery as there is no protection for two women slaves. The ethics of care are altered because Lina does not hesitate to put Sorrow's baby in the river, although it is not clear if the baby is alive as Sorrow thinks it is. Nevertheless, Lina does not act with the intention of hurting her. She simply acts according to her instincts to ensure their immediate survival and, to maintain a peaceful existence on the farm, as she is close to Rebekka. Even though the alteration of ethics of care does not necessarily represent lack of solidarity among the women characters, the discrepancy of behavior and expectation causes a distancing between Lina and Sorrow.

In this context, in both Sula and A mercy, slavery and its aftermath change the ethics of care which alters the characters' behaviors. The women characters' actions do not reflect

\footnotetext{
${ }^{32}$ BRYANT. The orderliness of disorder: madness and evil in Toni Morrison’s Sula, p. 739.

${ }^{33}$ MORRISON. A mercy, p. 123.

${ }^{34}$ MORRISON. A mercy, p. 123.
} 
conventional attitudes of solidarity and attachment, even though they do care about each other. In this sense, solidarity is usually present among the women characters; however, their actions differ according to their beliefs, experiences and struggles to survive in a racist and sexist society.

It is important to consider that the alteration in the ethics of care influences the characters differently based on their gender, race, and class. Although most characters in both novels resort to unconventional actions to express care, many succumb to the changes in the ethics of care by truly incorporating its damaging aspects. Such is the case with Rebekka, who at first establishes a sisterhood bond with Lina and treats Sorrow, Florens and the other slaves well, in marked contrast to the treatment they receive from the conservative, religious, racist villagers. However, by the end of the novel, she changes completely.

During Rebekka's illness she constantly thinks about her sufferings and the losses of her children and husband. When she recovers, she is transformed into a different person, cold and distant, as Florens mentions: "Mistress has cure but she is not well. Her heart is infidel. All smiles are gone" ${ }^{35}$ She notices that although Rebekka is not sick anymore, she is not the same lively woman she used to be. Willard and Scully also notice her change and each comment on her strange behavior from a different perspective. Willard says: "Rising from her sickbed, she had taken control, in a manner of speaking, but avoided as too tiring tasks she used to undertake with gusto (...) planted nothing (...) her time spent reading a Bible or entertaining one or two people from the village.”36 Rebekka is traumatized by her lack of power to do anything to help her children, her husband and even herself, when she was sick. She seems to try to acquire some control by adopting the principles of her religiously conservative and prejudiced community which calls for mistreating slaves and maintaining control by acting based on the superiority of race. Scully mentions that he observes "when she beat Sorrow, had Lina's hammock take down, advertised the sale of Florens". ${ }^{37}$ Rebekka no longer allows Lina to express herself and live by her beliefs. She becomes jealous of Sorrow's baby, hitting her and making her sleep outside in the cold with her baby and decides that Florens is to be sold. Rebekka associates Florens with her daughter Patrician because she was a little girl when she died and, around the same time, Jacob buys Florens when she is still a child. By disposing of Florens, Rebekka tries to dissociate herself from her past in an attempt

\footnotetext{
${ }^{35}$ MORRISON. A mercy, p. 159.

${ }^{36}$ MORRISON. A mercy, p. 145.

${ }^{37}$ MORRISON. A mercy, p. 155.
} 
to forget the suffering she underwent and erase the feeling of solidarity she used to share with them. It seems as if she suddenly becomes aware that she had tried to live ethically according to her beliefs but it only brought her harm. For that reason she then decides to act like everybody else in her village. Thus, Rebekka shows an alteration in the ethics of care as she dismisses her feelings for Lina, Sorrow, Florens and the other workers, while trying to assume a role of superiority based on race and class. Even so, Rebekka should not be judged too harshly because although her actions are cruel, she reflects the inhuman principles of the slave holding society she decides to side with, which clearly alters any ethics of care.

In Rita Bergenholtz's analysis of Sula, she shows that there is no clear cut way to judge the women characters' actions by asking some pertinent questions: "Should we admire Sula's courage, her determination to be free and to 'make herself'? Or should we loathe her for engaging in casual sex with her best friend's husband?."38 Similarly, Lina's, Rebekka's, Eva's and Sula's actions can, in fact, be viewed through different perspectives which may even be contradictory. As Florens enquires in her narration at the beginning of A mercy: "One question is who is responsible?.”39 In these complex and intricate narratives, it is difficult, if not impossible, to say who is to blame for the misfortune that befalls several women characters. Deborah McDowell also mentions that in Sula:

The narrative insistently blurs and confuses (...) binary oppositions. It glories in paradox and ambiguity beginning with the prologue that describes the setting, the Bottom, situated spatially in the top. We enter a new world here, a world that demands a shift from an either/or orientation to one that is both/ and, full of shifts and contradictions. ${ }^{40}$

Thus, the narrative is interwoven with mysteries and boundaries that are not fixed but rather flexible as the characters are trying to care for themselves and others. A parallel can be made between Sula and A mercy as it is impossible to judge the characters through simplistic views and dichotomous analysis of goodness and evil. Certain instability in the women characters' actions may be said to be caused by slavery and its aftermath which often blurs distinctions between right and wrong. The characters' actions need to be considered in relation to what they have experienced. In this sense, women characters and their attitudes cannot be divided into binary oppositions because they are often responding to some form of

\footnotetext{
${ }^{38}$ BERGENHOLTZ. Morrison's Sula: a satire on binary thinking, p. 92.

${ }^{39}$ MORRISON. A mercy, p. 3.

${ }^{40}$ MCDOWELL. "The self and the other”: reading Toni Morrison's Sula and the black female text, p. 80.
} 
alteration of the ethics of care. Although they may still show solidarity among themselves, they are forced to shape their actions differently from expected demonstrations of concern, sometimes even succumbing to the altered ethics of care.

\begin{abstract}
RESUMO
Neste artigo, argumento que nas obras Sula e A mercy, de Toni Morrison, ocorre alteração da ética do cuidado, considerando que as personagens recorrem a ações não convencionais para sobrevierem e cuidar do próximo em uma sociedade racista e machista. Demonstro que essas mudanças têm diversas implicações para as personagens.
\end{abstract}

\title{
PalaVRas-ChaVe
}

Ética do cuidado, Sula, A mercy

\section{REFERENCES}

BAKERMAN, Jane S. Failures of Love: female initiation in the novels of Toni Morrison. 1981. American Literature. Disponível em: <http://www.jstor.org>. Acesso em: 22 jul. 2009.

BERGENHOLTZ, Rita. Morrison's Sula: a satire on binary thinking. 1996. African American Review. Disponível em: <http://www.jstor.org>. Acesso em: 3 nov 2009.

BRYANT, Cedric Gael. The orderliness of disorder: madness and Evil in Toni Morrison's Sula, 1990. Black American Literature Forum. Disponível em: <http://www.jstor.org>. Acesso em: 6 nov. 2009.

DAVIES, Carole Boyce. Black women, writing and identity: migrations of the subject. New York: Routledge, 1994.

DAVIS, Angela. Women, Race, and Class. London: The Women’s Press, 1982.

GILLESPIE, Diane; KUBITSCHEK, Missy Dehn. Who cares? Women-centered psychology in Sula. 1990. Black American Literature Forum. Disponível em: <http://www.jstor.org>. Acesso em: 7 Mar. 2010.

HELD, Virginia. The ethics of care: personal, political and global. Oxford: Oxford University Press, 2006.

HENDERSON, Mae C. Pathways to fracture: African American mothers and the complexities of maternal absence. 2009. Black Women, Gender, and Families. Disponível em: <http://www.muse.jhu.eu>. Acesso em: 7 nov. 2009. 
HOOKS, bell. Sisters of the yam: black women and self-recovery. Boston: South End, 1993.

HOOKS, bell. Yearning: race, gender, and cultural politics. Boston: South End, 1990.

MCDOWELL, Deborah E. “The self and the other”: reading Toni Morrison's Sula and the Black female Text. In: MCKAY, Nellie (Ed.). Critical essays on Toni Morrison. Boston: Hall, 1988. p. 77-90.

MORRISON, Toni. A mercy. New York: Alfred A. Knoff, 2009.

MORRISON, Toni. Sula. New York: Penguin, 1973.

RICH, Adrienne. Of woman born: motherhood as experience and institution. 2. ed. New York: W. W. Norton \& Company, 1986.

SEVENHUIJSEN, Selma. Citizenship and ethics of care: feminist considerations on justice, morality and politics. Trans. Liz Savage. New York: Routledge, 1998.

WILLET, Cynthia. Maternal ethics and other slave moralities. New York: Routledge, 1995. 